\title{
The Audiences' Preferences on Advertisement Stimulus in Improving Brand Awareness: Shopee Baby Shark Version
}

\author{
Roos Nana Sucihati \\ Banking Finance \\ Universitas Samawa \\ Sumbawa Besar, Indonesia \\ roosnanasucihati@universitas- \\ samawa.ac.id \\ Binar Dwiyanto Pamungkas \\ Economic development \\ Universitas Samawa \\ Sumbawa Besar, Indonesia \\ binardwiyanto@universitas-samawa.ac.id
}

\author{
Elly Karmeli \\ Economic development \\ Universitas Samawa \\ Sumbawa Besar, Indonesia \\ ellykarmeli@universitas-samawa.ac.id
}

\author{
S Suprianto \\ Economic development \\ Universitas Samawa \\ Sumbawa Besar, Indonesia \\ suprianto@universitas-samawa.ac.id
}

\begin{abstract}
The study aims to determine the audiences' preferences on advertisement stimulus in baby shark Shopee version, namely heard and sound effects, music, words, pictures, color, and movements in improving brand awareness in Sumbawa Regency. This study applied an associative research method that aims to determine the relationship between the variables. 100 respondents were determined using a purposive sampling technique with the criteria of having watched the advertisement of Shopee baby shark version more than once. The primary data obtained from the questionnaire and were tested using multiple linear regression analysis techniques, statistical $t, f$ tests, and determination with the application of statistical packages for the social sciences (SPSS). The results show that the audiences' preferences have a significant effect in increasing brand awareness in Sumbawa Regency, either partially or simultaneously. The stimulus ability in the advertisement of Shopee baby shark version in influencing changes in brand awareness was $76.5 \%$, while the rest is influenced by other factors outside the study.
\end{abstract}

Keywords - Advertisement stimulus, shopee advertisement, baby shark version, brand awareness

\section{INTRODUCTION}

Promotion is one of the communication programs and has an inseparable role in marketing. Every company carries out promotions to publicize its products to raise awareness, which then forms an interest and ultimately makes a purchase made by the customer for the company's products or services.

Advertising is the most common promotional tool used by companies to inform, persuade, and remind target buyers or the public. The essence of advertising is to put something in the minds of consumers, change the perception of consumers and encourage consumers to act. Therefore, for a product brand to be accepted by the public, advertising must be made as effective as possible, creative and attractive so that it can have a positive influence in building awareness [1].

Through advertising, the company expects the audience to have high brand awareness so that when the audience needs a product, the brand that first appears in the minds of the audience is a brand that has high brand awareness in the minds of the public or a top of mind position. Top of mind is a situation where the product brand is directly mentioned once the person is asked about the product category [2].

According to Rossiter and Percy [3], brand awareness is the consumer's ability to identify (either recognize and remember) a brand with certain details to purchase. Another view states that brand awareness is the potential consumer's ability to recognize or recall that a brand is part of a particular product category [4].

Thus, consumers will certainly choose a product that is better known rather than buying an unknown product. Brand awareness enables producers to increase the sales of their products. Therefore, gaining consumer awareness is one of the marketing targets of producers.

The producers are trying to find out various strategies to advertise its products so that brand awareness is embedded in the audience's top of mind position. Television is a medium that is considered effective for advertising. Television (TV) has a strong ability to influence or even build perceptions of target audiences and consumers. Thus, generally, it can be concluded that advertising may help increase sales [5].

The advantages of television advertising compared to printing advertising enable the receipt of three generators of meaning at once, namely narration, sound, and visual. All of those three acts to form a signalling system that works to influence their audience. Advertising does not merely reflect the reality of the benefits of the product being offered but also is often a representation of the hidden ideas behind its creator. The issue of representation is then more interesting because in advertising a sociocultural meaning is constructed [6].

In 2019, Nielsen Advertising Intelligence (Ad Intel) announces the results of research that reveal television is an advertising medium that is still popular and effective by advertisers [7]. Meanwhile, Tjiptono [8] uncovers the advertisements on television are still the most popular one of advertiser companies. 
The advantage of television in its audio-visual nature is that it makes the advertisements appear more attractive because it is not only sound or image but also both. The amount of television share as the advertising media that most attract the viewer's attention is due to several elements, namely: heard and sound effects, music, words, picture, colour, and movements [3].

One company that uses television as an advertising medium for its promotional activities is Shopee. Shopee is an electronic trading platform headquartered in Singapore under the SEA Group. Shopee was founded in 2009 by Forrest Li. Shopee was first launched in Singapore in 2015 and has expanded its reach to Malaysia, Thailand, Taiwan, Indonesia, and other countries. If Shopee is compared to other marketplace sites, it is the youngest and lacks experience among the others. However, it is able to stand in line with its predecessors with the intense promotion of e-commerce [9].

One of Shopee's advertisements that remembered by its viewers is the baby shark. This advertisement is created by utilizing the six elements namely heard and sound effects, music, word, picture, colour, and movements. It is not surprising if it can attract attention and loved by the community. Many positive comments provided on the internet such as on www.youtube.com, Edrayahya blogs, and several other blogs.

This advertisement uses a positive emotional approach theme. The idea carried on this advertisement is to show a very lively atmosphere, dancing with contrasting colour combinations, good animation, interesting sound effects, and using the accompaniment of a popular musical jingle, namely baby sharks, so that it evokes cheerful feelings, joy in the hearts of the viewers.

The idea of the Baby Shark advertisement is actually also similar to other advertisements that utilize electronic media as advertising media. A research conducted by Kurniati [10] proves that visuals, music, and figures in the Pocari Sweat advertisement "Youth Sweat Beautiful" version have a significant effect both partially and simultaneously on brand awareness. Another research conducted by Eriko [11] which shows that the advertisement of Oreo Ice Cream Orange version 'Afika' is able to build a high level of brand awareness of Oreo Ice Cream Orange.

The emergence of various electronic trading platforms is currently increasing market competition, but Shopee can communicate its products well so that it is still able to gain brand awareness from its consumers. This phenomenon is the background of the researchers to conduct the research entitled " The Audiences' Preferences on Advertisement Stimulus in Improving Brand Awareness: Shopee Baby Shark Version.

\section{METHODS}

This study used an associative research method to test the relationship of the advertisement stimulus in baby shark Shopee advertisement, namely heard and sound effects, music, words, pictures, color, and movements in increasing brand awareness. There were 100 respondents who determined by using a purposive sampling technique. The primary data collected from field surveys using questionnaires and tested using multiple linear regression analysis techniques, $\mathrm{t}$, f statistical tests, and determination with the
Statistical Package For The Social Sciences (SPSS) application.

\section{RESULT AND DISCUSSION}

\section{A. Multiple Linear Regression Analysis}

Multiple regression analysis in this study used to determine changes in brand awareness variables caused by changes in variables heard and sound effect (X1), music (X2), word (X3), pictures (X4), color (X5), and movement (X6). Based on the output of data processing using SPSS obtained the following regression equation.

Brand Awareness $=-7,630+0,341$ Heard and Sound Effect + 0,698 Music + 0,284 Word + 0,546 Picture + 0,425 Color $+0,480$ Movement

The equation indicates that:

1. Constants of $-7,630$, can be interpreted if the variable heard and sound effect (X1), music (X2), word (X3), picture (X4), color (X5), and movements (X6) equal to zero, then the brand awareness $(\mathrm{Y})$ of $-6,630$.

2. Regression coefficient $\mathrm{b} 1=0.341, \quad \mathrm{~b} 2=0.698$, $\mathrm{b} 3=0.284, \mathrm{~b} 4=0.546, \mathrm{~b} 5=0.425$ and $\mathrm{b} 6=0,480$, if the $\mathrm{X}_{\mathrm{i}}$ variable increases by one, then brand awareness (Y) will increase by the value of the assumption coefficient regression the other $\mathrm{X}$ variables towards brand awareness (Y) are considered constant.

\section{B. Statistical T-Test}

The statistical t-test is used to measure the extent of influence of an independent variable partially (individually) on the variation of the dependent variable changes. The statistical t-test is performed by comparing the value of $\mathrm{t}$-count with t-table, an independent variable is categorized to have a partial effect on changes in the dependent variable if the tcount obtained is greater than the t-table value.

Based on the results of the statistical t-test, the stimulus variables contained in the advertisement consisting of the variables of heard and sound effects, music, word, picture, color, and movements have a t-value greater than the value of the table. Comparison of t-count to the t-table values of advertising stimulus variables is 3.183>1.986 for the heard and sound effect variable, 6.956>1.986 for the music variable, $2.276>1.986$ for the word variable, $4.169>1.986$ for the picture variable, 2.012>1.986 for the color variable and $2,644>1,986$ for the movement variable. It means partially those variables had a significant effect on improving brand awareness in Sumbawa Regency.

\section{Statistical F-Test}

The statistical f-test is used to measure the effect of the independent variables simultaneously on the variation of the dependent variable changes. The statistical f-test is done by comparing the value of f-count with f-table, independent variables are categorized to have a simultaneous effect on changes in the dependent variable if the f-count value obtained is greater than the f-table value.

Based on the results of the statistical f-test, the stimulus variables contained in the advertisement consisting of the variables heard and sound effect, music, word, picture, color, 
and movements have an f-count value greater than the f-table value. The calculated value of stimulus variables contained in advertisements in improving the brand awareness in Sumbawa Regency is 50.505, while the f-table value is 2.170 $(50.505>2.170)$. This means that simultaneously the stimulus variables of advertisements consisting of heard and sound effects, music, words, pictures, colors, and movements have a significant effect on increasing brand awareness in Sumbawa Regency.

\section{Determination Coefficient Test $(R 2)$}

The determination coefficient test $\left(\mathrm{R}^{2}\right)$ is done to measure how much the model's ability to explain the dependent variable, the greater the value (close to one), the stronger the influence of the independent variables on the dependent variable. Vice versa.

Based on the results of the determination coefficient test $\left(R^{2}\right)$ shows that the Adjusted $R$ Square $\left(R^{2}\right)$ value is 0.835 . It means that the six stimulus elements contained in the Shopee Baby Shark Version namely heard and sound effects, music, word, picture, color, and movements in influencing brand awareness changes in Sumbawa Regency are $76.5 \%$, while the remaining $23,5 \%$ is influenced by other factors outside the study.

Advertising is a form of promotion that is often used to attract consumers' attention. Advertising is commercial and non-personal communication about an organization and its products that are transmitted to the target audience through mass media such as television, radio, newspapers, magazines, direct mailing (direct posting), or outdoor billboards.

Television advertising is the most effective medium to promote the products or services produced. Creativity is needed to create a link between advertising with positive emotional feelings. To attract the attention and liking of viewers, then the advertisement must be packaged in a creative and innovative theme by utilizing the elements and stimuli contained in it.

Creativity in advertising is needed in creating a link between advertising and emotional factors. Advertisement is expected to get a place in the hearts or likes of the viewers. The attitude of viewers to the adverts can be investigated through like or dislike of the stimuli displayed in the advertisement. These responses and reactions are obtained from images or colors, words that are heard (sounds) or written words, music, and other special effects or movements contained in advertisements.

Nowadays many companies advertise their products through various media both print and electronic media. A company that uses electronic media to promote its products is Shopee. To create brand awareness among consumers, Shopee carries out promotional activities such as the baby shark version of advertising by utilizing six stimuli to attract viewers' attention, namely heard and sound effects, music, word, picture, color, and movements.

The results of the study showed that the stimulus variable contained in the advertisement of baby shark version consisting of heard and sound effects, music, word, picture, colour, and movements had a significant effect on improving brand awareness in Sumbawa Regency, both partially and simultaneously. It means that this advertisement can create brand awareness of Shopee consumers in Sumbawa Regency

This is in line with the views of Rossiter and Percy [3] which states that the audience will respond to the stimulus contained in an advertisement through the elements contained in the adverts which can attract attention and cause liking to the viewers, namely sound and sound effects, music, word, picture, color, and movements. A creative advertisement that utilizes these elements can move people from not being aware of a brand until they finally buy the brand.

The results of this study are supported by the results of a previous study conducted by Kurniati [10] entitled The Effect of the Youth Sweat Beautiful Pocary Sweat Advertising Stimulus on brand awareness in students of Gunadarma University Kalimalang Jakarta. The elements and advertising stimulus used in this study are visuals, music, and figures in the youth sweat beautiful advertisement for Pocary Sweat. The research findings show that the advertisement stimulus is in the youth sweat beautiful version of Pocary Sweat advertisement, namely visuals, music, and figures that have a significant effect both partially and simultaneously on brand awareness in the students of Gunadarma University, Kalimalang, Jakarta.

\section{CONCLUSION}

Based on the results of data analysis and discussion previously described, several conclusions can be taken as follows. Partially the stimulus contained in the Shopee advertisement in the baby shark Shopee version, namely heard and sound effects, music, words, pictures, colours, and movements have a significant effect in increasing brand awareness in Sumbawa Regency. Simultaneously the stimulus contained in the Shopee advertisement in the baby shark version namely heard and sound effects, music, words, pictures, colours, and movements have a significant effect in increasing brand awareness in Sumbawa Regency. The stimulus capability contained in the Shopee advertisement in the baby shark version, which is heard and sound effects, music, word, picture, colour, and movements in influencing changes in brand awareness in Sumbawa Regency is $76.5 \%$, while the remaining $23.5 \%$ is influenced by other factors outside the study.

Based on these conclusions, the recommendations that the author can give are as follows. For business communities, in a competition or even to win the competition, every company must design creative and innovative advertisements by utilizing the six elements and stimuli contained in the advertisements, namely voice, music, word, picture, colour, and movements, to attract attention and cause people's fondness. For further researchers, this research is a quantitative study, further research should conduct similar qualitative research to obtain a richer and deeper description of respondents' responses to an advertisement.

\section{REFERENCES}

[1] Riyanto, Bambang. 2008. Dasar-dasar Pembelanjaan Perusahaan. Yogyakarta: BPFE.

[2] Widyatama, Rendra. 2005. Pengantar Periklanan. Jakarta: Buana Pustaka Indonesia. 
[3] Rossiter, John R dan Percy, Larry. 2007. Advertising and PromotionManagement. United State of America: Mc Graw-Hill Book Company.

[4] Rangkuti, Freddy. 2013. The Power Of Brands. Jakarta: PT Gramedia Pustaka Utama.

[5] Dharmmesta, Basu Swastha. 2014. Manajemen Pemasaran. Yogyakarta: Liberty.

[6] Burton, Graeme. 2007. Membincangkan Televisi (Sebuah Pengantar Kepada Studi Televisi). Bandung: Jalasutra.

[7] Retrieved from www.nielsen.com, 15 November 2020.
[8] Tjiptono, Fandy. 2015. Strategi Pemasaran. Edisi 4. Yogyakarta: Andi Offset.

[9] Retrieved from http://thidiweb.com, 17 November 2020.

[10] Kurniati, Lintang. 2012. Pengaruh Stimulus Iklan Televisi Pocary Sweat Versi Youth Sweat Beautiful terhadap Brand Awareness Pada Mahasiswa Universitas Gunadarma Kalimalang. Skripsi. Jakarta: Universitas Gunadarma.

[11] Eriko, Ravid; Agus Setiaman; Pramono Benyamin. 2012. Tayangan Iklan Produk dalam Membangun Kesadaran Merek. E-Jurnal Mahasiswa Universitas Padjadjaran Vol.1., No.1 (2012). 